\title{
Evaluating grazing strategies for cattle: Nutrition of cattle and deer
}

\author{
ISAAC M. ORTEGA, SERGIO SOLTERO-GARDEA, D. LYNN DRAWE, AND FRED C. BRYANT
}

Authors are research associate, former graduate student, assistant director, and former professor, Department of Range, Wildlife, and Fisheries Management, Texas Tech University, Lubbock, Tex. 79409-2125 (IMO); Instituto Nacional de Investigaciones Forestales y Agropecuaries, Jalisco, Mexico (SSG); and Welder Wildlife Foundation, Sinton, Tex. (DLD), and Caesar Kleberg Wildlife Research Institute, TAMU-Kingsville, Kingsville, Tex. 78363 (FCB).

\begin{abstract}
We studied cattle and deer diet quality within replicated grazing treatments of continuous and short-duration grazing at heavy and moderate stocking rates. The study was conducted at the Welder Wildlife Refuge, Sinton, Tex. from October 1987 to July 1989. We obtained cattle diet samples from esophageally fistulated steers. Deer diets were reconstructed using data obtained through the bite-count technique. Digestibility (IVDOM) and crude protein (CP) of cattle diets were similar between grazing systems and stocking rates. Digestibility of deer diets was affected by both grazing systems and stocking rates. Dietary CP and IVDOM of deer and cattle diets both differed among seasons. Dietary CP levels met maintenance requirements for deer throughout the study. Also, CP levels were high enough to meet low- to mid-gestation requirements. Deer dietary protein requirements for growth and lactation were never met regardless of graxing strategy. Although protein content of cattle diets was relatively low, these values satisfied cattle maintenance needs. Nursing cows, however, would not have met their requirement in any season sampled regardless of grazing system or stocking rate. Continuous grazing and moderate stocking rates may provide white-tailed deer the opportunity for selecting diets containing more desirable forbs and greater nutrient concentration. Less intensive rotational grazing at moderate rates may be preferred to maintain a relatively high seral stage.
\end{abstract}

Key Words: crude protein, IVDOM, digestibility, Coastal Bend of Texas, short-duration grazing, continuous grazing, Odocoileus virginianus

One of the most important components of deer and livestock management is nutrition which determines their productivity and survival rates (McMahan and Ramsey 1965; Teer et al. 1965;

Authors thank J. Teer, J. Cox, B. Martinez, I. Berger, M. Roderick, K. Weddle, and many others for their contribution in the field and lab work. We would also like to thank D. Haukos for assistance in statistical analyses and K. Launchbaugh, C. Britton, and R. Mittchell for their critical reviews and suggestions on early drafts of this manuscript.

This is a Welder Wildlife Foundation contribution No. 477 and a College of Agriculture and Natural Resources TTU publication T-9-749. This research was also supported by the Office of Agriculture, Bureau of Research and Development, U.S Agency for International Development under Grant No. DAN-1328-G-00-0046-00.

Manuscript accepted 22 Dec. 1996.
Resúmen

Estudiamos la calidad de la dieta de los ciervos de cola blanca y vacunos en tratamientos replicados de pastoreo continuo y de corta duración bajo cargas animales altas y moderadas. El estudio fue llevado a cabo entre octubre de 1987 y julio de 1989 en el Refugio de Vida Silvestre Welder, Sinton, Tex. Obtuvimos las muestras de dieta del vacuno a través del uso de novillos fistulados al esófago. Las dietas de los ciervos fueron reconstituidas a través del uso de datos obtenidos por la técnica de contéo de mordiscos. La digestibilidad (IVDOM) y la proteína cruda (CP) de la dieta de los vacunos fué similar entre los sistemas de pastoreo y las cargas animales. La digestibilidad de la dieta de ciervos fue afectada tanto por los sistemas de pastoreo como por las cargas animales. Tanto la IVDOM como la CP de las dietas de ciervo y vacuno fue diferente a lo largo de las estaciones del año. Los niveles de CP fueron suficientemente alto para los requerimientos de mantención de los ciervos a través del estudio. Más aún, los niveles de CP fueron suficientemente altos como los requirimientos de los niveles bajo a medio de los ciervos durante la gestación. Los requerimientos de proteína para los ciervos no fueron suficientemente altos para el crecimiento y la lactación independiente de la estrategia de pastoreo. Aunque los niveles de proteina de la dieta del vacuno fue relativamente baja, fueron lo suficientemente altos como para reunir las necesidades de mantención. Sin embargo, vacas durante el periodo de lactación no podrian haber alcanzado estos requerimientos en ninguna estación del año, independiente del sistema de pastoreo o de la carga animal. Un pastoreo continuo con una carga moderada pudieran proveer al ciervo de cola blanca la oportunidad de seleccionar dietas que contengan hierbas deseables y con una mayor concentración de nutrientes. El pastoreo de rotación menos intensivo con carga moderada deberian ser preferida a modo de mantener un estado de sucesión relativamente alto.

Knowlton et al. 1978; Kie et al. 1980). Many factors contribute to change the composition and quality of cattle and deer diets, such as animal preference, forage availability, season, weather, range site, range condition, deer population density, stocking rate, grazing pressure, deer age, range improvements, and grazing management (Chamrad et al. 1978; Holechek et al. 1982a, 1982b; Vavra et al. 1973).

Research to determine the nutrition of grazing animals during phenological stages of vegetation and under different seasons is 
necessary to identify periods of nutrient deficiency. Livestock management strategies can affect deer nutrition. Adjustments of stocking rate, grazing periods, pasture deferment, and even supplementation programs may be required to maintain a healthy and productive deer population.

Studies of different sampling procedures, range conditions, seasons, and grazing systems have documented composition and nutritional value of cattle diets in the Texas Coasi: Bend (Drawe 1967; Durham 1975; Frasure et al. 1978; Draw 988), or in the South Texas Plains (Everitt et al. 1981). Howev studies of deer nutrition in South Texas have only been conducted under penned conditions (Drawe 1968; Everitt and Drawe 1974; Short 1971, 1975; Chamrad et al. 1978; Arnold and Drawe 1979; Kie et al. 1980). Little information on nutritional status of free-ranging white-tailed deer (Odocoileus virginianus Boddaert) is available in the Texas Coastal Bend.

Bryant et al. (1979) found that a 4-pasture, 3-herd grazing system kept study pastures in good to excellent condition for cattle with increased availability of grass regrowth, which in turn contributed to a higher nutritive value of deer forage. Furthermore, white-tailed deer diets from pastures in excellent condition for cattle were higher in crude protein throughout the year than diets from poor condition range (Bryant et al. 1981). Warren and Krysl (1983) suggested that control of livestock grazing and big game numbers is necessary to maintain a high nutritional plane for white-tailed deer in central Texas. Meyer et al. (1984) determined the crude protein and energy content of white-tailed deer diets in the Texas Coastal Bend and concluded that the low quality of late summer diets could impact negatively white-tailed deer populations. Soltero et al. (1994) suggested energy is a limiting factor for deer in the Texas Coastal Bend region.

Despite information available on food habits and nutrition for white-tailed deer in general, no information is available on the effect of grazing systems and stocking rates on nutrition, particularly in the Texas Coastal Bend. Information is needed regarding the effect of intensive grazing strategies such as short-duration grazing. Our objectives were to determine the nutrient content of cattle and white-tailed deer diets under 2 grazing systems, continuous yearlong and short-duration, and under 2 stocking rates, heavy and moderate, in the Texas Coastal Bend; and to evaluate how season affects nutrient content of cattle and deer diets.

\section{Materials and Methods}

The study was conducted at the Rob and Bessie Welder Wildlife Foundation Refuge. The Welder refuge is located in the Coastal Bend Region about 35 miles northwest of Corpus Christi, Tex. A detailed discussion of the study site is found in Ortega et al. (1997a).

Four treatments were evaluated to determine the effect of stocking rate and grazing system on the quality of deer and cattle diets. The grazing systems evaluated were short-duration and continuous-yearlong. Two different stocking rates were studied in each grazing system: a moderate rate ( $4.9 \mathrm{ha} / \mathrm{AUY}$ ), which was designed to achieve $50 \%$ use of the vegetation, and a rate that was 2 times the moderate stocking rate $(2.4 \mathrm{ha} / \mathrm{AUY})$. The normal or moderate stocking rate $(4.9 \mathrm{ha} / \mathrm{AU})$ was based on data from more than 25 years of study at the Welder Wildlife Refuge (Drawe and Cox 1978). All treatments were replicated twice and were assigned randomly within grazing systems. Short-duration replications were established to simulate the effects of grazing 1 pasture in an 8-pasture system.

Grazing history of each site was described by Drawe and Cox (1978). Grazing of the study pastures to achieve treatment conditions began in October 1987, and continued until July, 1989. Sampling periods were grouped into seasons and were established according to phenology of the vegetation and climatic patterns (Table 1).

Table 1. Sampling periods established during the study. Weider Widlife Refuge, 1987-1989.

\begin{tabular}{lcc}
\hline \hline Season & Year 1 & Year 2 \\
\hline Fall & Oct.-Nov. 1987 & Oct. -Nov. 1988 \\
Winter & Dec. 1987-Feb. 1988 & Dec. 1988-Feb. 1989 \\
Spring & Mar--Apr. 1988 & Apr--May 1989 \\
Summer & May-Sep. 1988 & Jun. -Jul. 1989 \\
\hline
\end{tabular}

The treatments were stocked with 2-yr old Hereford/Brahman heifers to accomplish the utilization desired on the study sites. Heifers at the continuous study sites remained there year-round, whereas, cattle under short-duration were moved every month from a pasture adjacent to the study sites. Each replication of short-duration was grazed 4 days and rested 28 days.

Nutritional value of deer diets was determined by using 10 tame does to observe their food habits. Five does were born in 1986 and 5 in 1987, and all of them were under similar physiological status. Detailed explanation on raising and care of deer used in this study are found in Ortega et al. (1990) and Ortega (1991). The sampling scheme consisted of 1-day sampling with 4 tame deer on each replicate of each treatment. This sampling was conducted simultaneously in all treatments on a monthly basis and yielded 4 samples/replicate and 8 samples/treatment. Tame deer had grazed an adjacent enclosure to become familiar with vegetation changes throughout the year.

Material representing plant species being consumed by deer was collected by hand plucking immediately after each day of sampling and, when possible, from the pasture or treatment being sampled. These plants were oven-dried at $55^{\circ} \mathrm{C}$, ground through a 1-mm screen in a Tecator mill, and mixed. A composite sample $(50 \mathrm{~g})$ of the species and their plant parts was prepared for each of the tame deer used in the study, based upon the percentage of each plant species in their diets.

Nutritional value of cattle diets was determined by using 10 esophageally fistulated steers. The sampling scheme consisted of a 2-day sampling period on each treatment and its replicates. Fistulated animals were kept in an adjacent area comparable to that of the study site for adaptation to the local vegetation changes. Esophageally fistulated steers were fasted overnight before each collection day. Sampling was conducted every month in all treatments concurrently. Steers were allowed to graze for 1 hour in each replicate. Samples were obtained in screen-bottom collection bags, drained 1 to 2 hour, thoroughly hand-mixed, oven dried at $55^{\circ} \mathrm{C}$, and ground through a $1-\mathrm{mm}$ screen in a Wiley mill according to conventional procedures for laboratory analysis (AOAC 1990). Samples were composited by animal within collection periods.

Samples of both deer and cattle diets were analyzed in duplicate and averaged for percent dry matter, organic matter, and percent nitrogen (expressed as CP) using the procedures described 
by Galyean (1984). In vitro digestible organic matter (IVDOM) was estimated using the first stage of the in vitro technique (48hour fermentation period) developed by Tilley and Terry (1963). Rumen fluid from a fistulated steer fed alfalfa hay was collected and used for digestibility analysis of deer and cattle samples. Inoculum from fistulated cattle to determine in vitro digestibility of deer diets has been used with positive results. Palmer et al. (1976) found that rumen fluid from cattle produced in vitro digestible dry matter (IVDDM) values that were less variable and more closely correlated with deer in vivo coefficients than those obtained with inoculum from fistulated deer.

Tables of nutrient requirements of domestic animals published by the National Research Council (NRC 1984) were used to compare dietary protein of cattle with $\mathrm{CP}$ requirements for different physiological activities. Values used in this discussion assumed a cow weight of $450 \mathrm{~kg}$ and 3 physiological stages: maintenance $(7 \% \mathrm{CP})$, which is also considered the requirement for a mature cow in the middle third of pregnancy; pregnancy $(7.9 \% \mathrm{CP})$, for cows in the last third of pregnancy; and lactation (9.9\% CP) for nursing cows (NRC 1984). Several values of CP requirements for deer from different authors were used to compare the results of deer dietary CP found in this study and those required at different deer ages or physiological conditions. This step was necessary given the fact that there are few studies in which the nutrient requirements of deer have been quantified (Verme and Ullrey 1984). For instance, French et al. (1956) estimated that the protein requirement for maintenance of mature deer was between 6 to $10 \%$. Murphy and Coates (1966) indicated that body weight and antler development of yearling and mature male deer were delayed when they were furnished with a $7 \% \mathrm{CP}$ diet. Whitetailed deer fawns could require 13 to $16 \%$ of $\mathrm{CP}$ for growth according to French et al. (1956). Ullrey et al. (1967), suggested that protein requirements for growth of fawns could range from 14 to $22 \%$. The latter percentages are thought to be adult does CP requirements for lactation (Verme and Ullrey 1984). These authors presumed that $\mathrm{CP}$ requirements for gestation and antler development were intermediate between those for growth and maintenance. Therefore, low and high limits of protein requirements used in this study were the following: 6 to $10 \%$ for maintenance, 8 to $18 \%$ for gestation and antler development, and 14 to $22 \%$ for growth and lactation.

Digestible energy (DE) for cattle was estimated from digestible organic matter using the regression equation: $\mathrm{DE}, \mathrm{Mcal} / \mathrm{kg} \mathrm{OM}=$ 0.039 (\% OM digestibility) -0.10 , developed by Rittenhouse et al. (1971). These values were compared to the NRC requirements for maintenance, pregnancy, and lactation by converting metabolizable energy (ME) to DE using the NRC conversion: DE, $\mathrm{Mcal} / \mathrm{kg}=\mathrm{ME} \times 1.22$ (Rosiere et al. 1975). The DE requirement for maintenance was $2.37 \mathrm{Mcal} / \mathrm{kg}$, whereas the requirement for lactation was $2.54 \mathrm{Mcal} / \mathrm{kg}$. A requirement of $2.37 \mathrm{Mcal} / \mathrm{kg}$ was estimated for dry pregnant cows in their last third of pregnancy. Digestible energy estimations for deer were determined using the same regression equation described previously. However, estimated DE values were compared to deer energy requirements cited by Moen (1973), which were determined using the energy requirement as a multiple of the basal metabolic rate (BMR). Body weights used were from data collected at the Welder Wildlife Refuge and were $45.4 \mathrm{~kg}$ for mature females and $20.4 \mathrm{~kg}$ for 4-month old fawns. Thus, DE requirement for lactation was estimated at 2.2 to $2.8 \mathrm{Mcal} /$ day, whereas $\mathrm{DE}$ for growth was 1.2 to $1.7 \mathrm{Mcal} /$ day. Maintenance and gestation DE requirements were estimated at $1.6 \mathrm{Mcal} /$ day and $1.8 \mathrm{Mcal} /$ day, respectively.

Data on diet quality of both deer and cattle were analyzed using the General Linear Model (GLM) of Statistical Analysis System (SAS 1985) through a completely randomized design with a splitplot in time arrangement (Steel and Torrie 1980). Pastures within grazing systems (GS) and stocking rates (SR) were considered replications (Rep). Grazing systems and stocking rates were whole plots with seasons as the split-plot. The error term for testing significant effects of grazing systems and stocking rate was Rep $\times$ SR (GS). Error term used for testing season was Rep $\times$ GS $\times$ SR $\times$ Seasons. Differences between means were determined using Fisher's protected least significant difference (LSD) procedure $(\alpha=0.05)$ (Ott 1988).

\section{Results and Discussion}

Digestibility (IVDOM) of deer diets was affected $(\mathrm{P}<0.05)$ by both grazing systems and stocking rates (Fig. 1). Deer IVDOM values under continuous grazing and heavy stocking rates were greater than those observed under short-duration grazing and moderate stocking rate. Dietary CP and IVDOM of cattle were similar $(P>0.05)$ between grazing systems and stocking rates (Fig. 1).
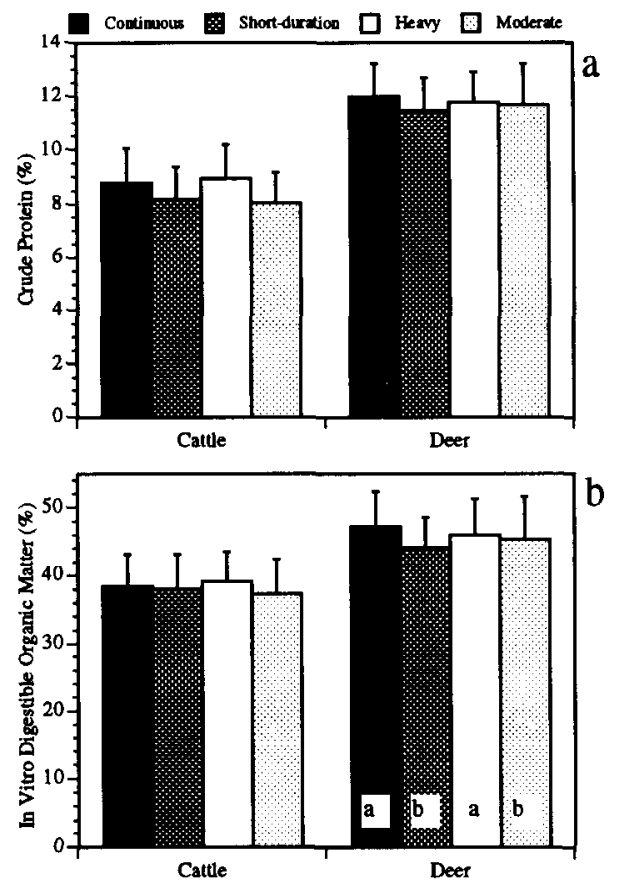

Fig. 1. Crude protein (a) and In vitro digestible organic matter (b) of deer and cattle diets under 2 grazing systems and 2 stocking rates. Grazing systems and stocking rates with different letters are significantly different $(P<0.05)$. Treatments with no letter are similar $(\mathbf{P}>0.05)$.

Differences $(\mathrm{P}<0.05)$ among seasons were found for dietary $\mathrm{CP}$ and IVDOM for both deer and cattle (Fig. 2). In fall of Year 1, deer diets were relatively low in CP and IVDOM. This may be 

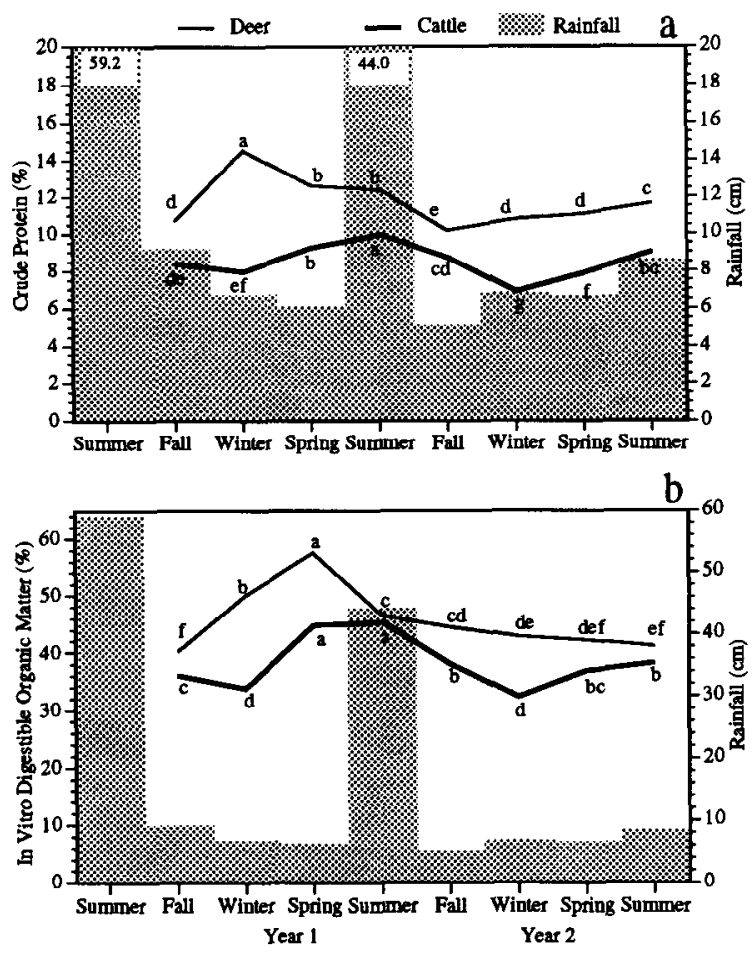

Fig. 2. Crude protein (a) and In vitro digestible organic matter (b) of deer and cattle diets under 2 grazing systems and 2 stocking rates, and rainfall at the Welder Wildlife Refuge since the summer 1987 to the summer of 1989. Diets with different letters within animal species are significantly different $(P<0.05)$.

explained by advanced plant maturity and possibly by high browse consumption (39\%). Forage availability, particularly that of forbs, was high at that time (Ortega et al. 1997b). Consequently, forage availability was not a factor that could have influenced the quality of deer diets during this season. An $(\mathrm{P}<$ 0.05) increase of dietary CP and IVDOM however, was detected as winter progressed. This was attributed to the presence of coolseason plants such as Texas wintergrass (Stipa leucotricha Trin \& Rupr.) and forbs that responded positively to the moderate precipitation recorded during that period (Fig. 2). Moreover, as a direct result of increased winter forb availability, forbs increased in deer diets by $30 \%$ and browse dropped by $35 \%$ (Ortega 1991, Ortega et al. 1997b). The highest digestibility of deer diets occurred in spring of Year 1, coinciding with the highest forb content in deer diets $(88 \%)$. However, dietary CP declined by $2 \%$. During the summer of Year 1, dietary CP did not change but IVDOM declined $(P<0.05)$. Herbage biomass was very low during this period $\left(162 \mathrm{~g} / \mathrm{m}^{2}\right)$ with approximately $22 \mathrm{~g} / \mathrm{m}^{2}$ of the total herbage biomass desirable forbs (Ortega et al. 1997a). Therefore, as availability of forbs declined deer were forced to consume browse which probably decreased diet digestibility. A similar phenomenon was observed during fall and winter of Year 2. Deer used about 55\% forbs and 22\% browse in winter (Ortega 1991, Ortega et al. 1997b). In spring and summer of Year 2, IVDOM coefficients were similar, yet $C P$ values were different $(P<0.05)$ between both seasons. Also, these results were different than those found in Year 2. Apparently, reduced precipitation during Year 2 resulted in the lower nutritive values of the forage. Forage availability declined by approximately $64 \%$ from fall of Year 1 to summer of Year 2 (Ortega et al. 1997a). Additionally, during the last 10 months of the study, precipitation was sporadic and below long-term monthly averages.

Dietary CP levels for deer in this study were lower than those reported in other studies. For example, Kie et al. (1980) found protein values as high as $21 \%$ during spring and as low as $15 \%$ during winter. However, Kie et al. (1980) determined CP using rumen contents and microbial protein contributes to increase the CP estimated when using this method.

Crude protein and IVDOM values of cattle diets were seasonally different $(P<0.05)$ (Fig. 2). Both nutrient curves followed similar trends with low values during fall and winter and high values during spring and summer. Durham (1975) observed similar trends in winter diets of cattle in the Texas Gulf Coast. Furthermore, both curves changed with rainfall patterns, i.e., CP and IVDOM values paralleled the precipitation pattern (Fig. 2). Forage availability declined and vegetation matured resulting in a decline of CP and IVDOM ( $P<0.05)$ from spring to summer and, in a predictable way, from summer to winter (Ortega et al. 1997a). As plants mature they become more lignified, reducing the nutritional value of the various forb species (Jones and Wilson 1987). It is important to note that in general, CP and IVDOM values were low despite the fact that cattle diets comprised a high proportion of forbs (25 to 55\%; Ortega 1991, Ortega et al. 1997b).

An interaction $(P<0.05)$ was observed between grazing systems and seasons for deer dietary CP and IVDOM (Fig. 3). During most of the seasons, continuous grazing provided higher forage quality than short-duration grazing. A possible explanation of this interaction is the lower consumption of grass by deer under short-duration grazing during spring in Year 2. Deer diets
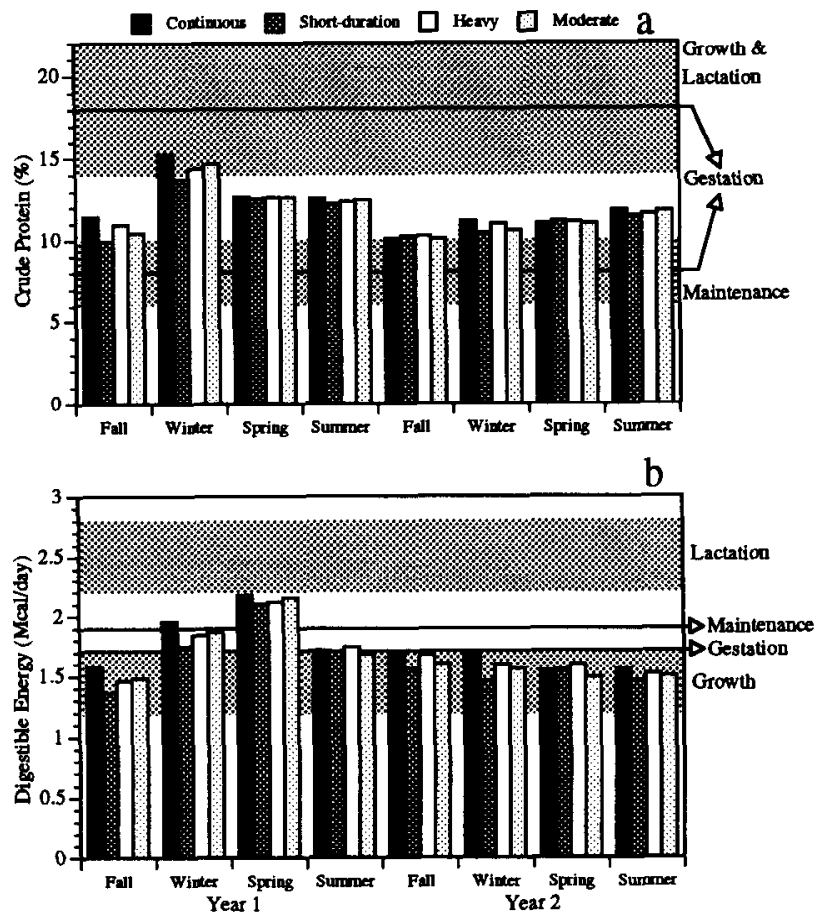

Fig. 3. Deer dietary crude protein (a) and digestible energy (b) under 2 grazing systems and 2 stocking rates compared with crude protein and energy requirements at Welder Wildlife Refuge. Arrows represent gestation range requirements of $\mathrm{CP}$ in (a); and maintenance and gestation requirement of digestible energy in (b). 
were $6 \%$ lower in grass than under continuous grazing (Ortega 1991, Ortega et al. 1997b). Grasses were of lower digestibility than other forage classes available at that time (Soltero et al. 1994).

For cattle, interactions for dietary $\mathrm{CP}(\mathrm{P}<0.05)$ were found between grazing systems and seasons and between stocking rates and seasons. In general, cattle dietary $\mathrm{CP}$ was greater under continuous grazing than short-duration grazing (Fig. 4a). The exception was during spring of Year 1. Cattle CP was greater under heavy than under moderate stocking rate during most seasons except winter of Year 1 (Fig. 4a). It was not clear what produced
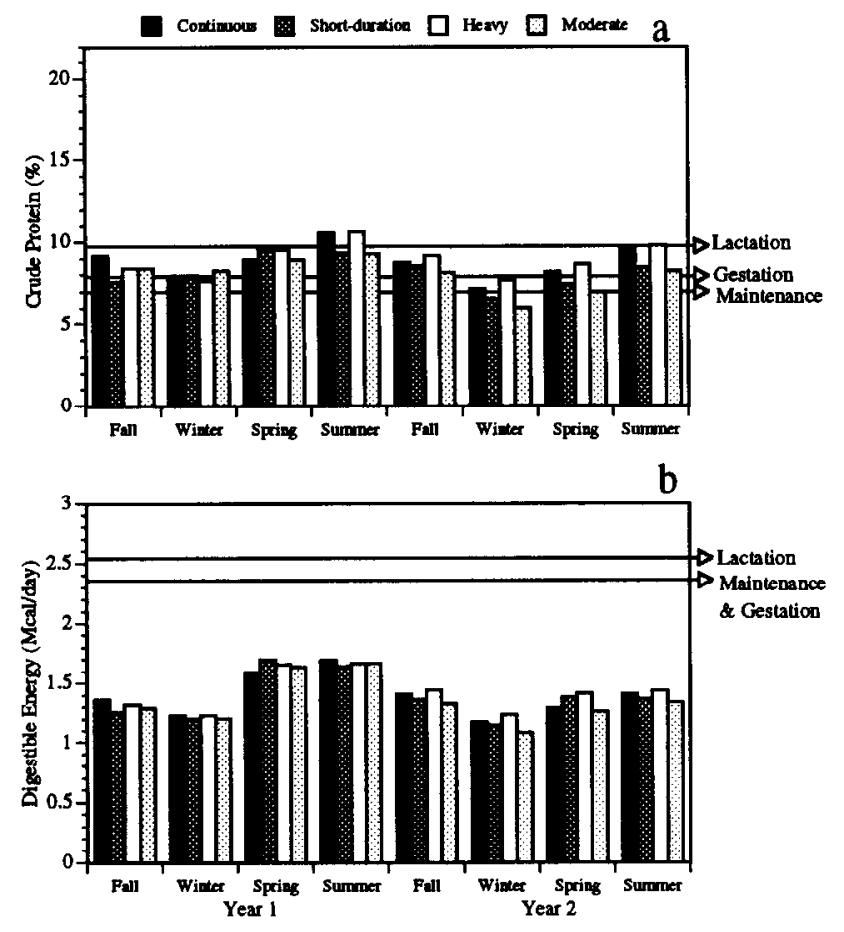

Fig. 4. Cattle dietary crude protein (a) and digestible energy (b) under 2 grazing systems and 2 stocking rates compared with crude protein and energy requirements at Welder Wildlife Refuge. Arrows represent gestation, maintenance and gestation requirement of CP in (a) and digestible energy in (b).

these interactions in either case. Cattle diets consisted of similar proportions of forbs and browse under both grazing systems during spring 1988, but cattle in short-duration grazing consumed 7\% more grass than under continuous grazing. Considering the CP content of grasses during winter (which was lower than forbs and browse), we expected cattle diets under continuous grazing would have had higher CP contents. Apparently grasses consumed under short-duration grazing were mostly cool-season grasses, such as Texas wintergrass which are characterized by their high $\mathrm{CP}$ content and are commonly found in cattle diets during this period. Drawe (1988) observed that Texas wintergrass peaked in cattle diets during December, January, and February. Another possible explanation could be the difference in total phytomass between grazing systems. In spring of Year 1, total phytomass availability was $39 \%$ higher under short-duration grazing than under continuous grazing. In terms of stocking rate, total phytomass was higher under moderate than under heavy stocking
(Ortega et al. 1997a), which could explain why cattle under the moderate rate were able to select a more nutritious diet.

When quality of deer and cattle diets under the treatments and seasons were compared with the nutritional requirements for the diverse physiological stages of both animal species, CP levels met the maintenance requirements for deer throughout the entire study period when $7 \%$ CP was considered as the average maintenance value (Fig. 3a). These results agree with those found by Meyer et al. (1984), who determined deer dietary CP in the Texas Coastal Bend. Bryant et al. (1981) also reported that CP values from hand-plucked deer diet samples never fell below $7 \%$. We observed that during fall of Year 1, and fall and winter of Year 2, these requirements were at the upper limits of maintenance requirements (10\% CP) regardless of grazing system or stocking rate. Deer protein values under both grazing schemes and stocking rates were high enough to meet the low to mid limits of the gestation requirement. White-tailed deer dietary $\mathrm{CP}$ requirements for growth and lactation under both heavy or moderate stocking rates were never met during the study, always remaining below the $14 \%$ minimum limit (Fig. 3a). Under the conditions of this study, growing and lactating white-tailed deer did not have an adequate supply of CP regardless of the grazing strategy.

Although CP content of cattle diets was relatively low (Fig. 4a), especially during winter, these values satisfied cattle needs for most of the physiological stages and for almost the entire study. However, there were periods in which not even the requirements for maintenance were met, particularly under short-duration grazing and moderate stocking rate ( 2 and 3 seasons, respectively). Under continuous grazing, on the other hand, winter of Year 2 was the only period in which dietary protein for cattle was below maintenance (Fig. 4a). Lactating cows would not have met their requirements in any season sampled, regardless of the grazing strategy used. The requirements for cows in their last trimester of pregnancy was not met on any grazing treatment. When the effect of stocking rate on the level of dietary CP for cattle and its relationship to $\mathrm{CP}$ requirements was examined, a similar trend was detected for grazing systems. Under heavy stocking, CP requirements for maintenance were more readily met than at the moderate rate. Further, dietary $\mathrm{CP}$ for cattle under both stocking rates was not adequate to meet the lactation and pregnancy requirements in any period when these activities took place.

Deer DE values were high enough to satisfy the maintenance requirements during most of the seasons (Fig. 3b). However, the $\mathrm{DE}$ requirements for gestation were only met during spring of Year 1, whereas energy requirement for lactation was never met in any of the seasons sampled regardless of the grazing strategy. Growth requirements, on the other hand, were met during all seasons (Fig. 3b). Energy values estimated for cattle diets were relatively low and were not adequate to meet any of the cattle needs in any period regardless of the grazing system or stocking rate (Fig. 4b).

Our results suggest that a combination of continuous grazing and heavy stocking rate was the grazing strategy that produced the best forage quality for deer and cattle (Fig. 3). Dietary CP and digestibility of deer diets were greatest under this grazing combination than in any other combination (Fig. 3) during 6 seasons, from fall of Year 1 to winter of Year 2. However, this contention only holds true as long as there is enough forage available to satisfy the energy requirements of both animal species. In our study, this did not happen. Although we did not estimate this, it is ques- 
tionable whether deer or cattle could have met their dry matter intake requirements, particularly during those periods in which forage availability declined significantly. Additionally, this situation could worsen because of the erratic precipitation and the recurrent drought periods that are common in this area. Precipitation during the study period was below the long-term average, in $\mathbf{2 0}$ of $\mathbf{2 2}$ months (Welder Wildlife Refuge rainfall data). Thus, the effect on forage availability was more noticeable during the second year of study.

Deer dietary CP levels and energy were generally low, particularly those during summer and fall. Energy values were especially low for lactating females during the dry year of 1989. Forage values for growing fawns seemed to be adequate. This lack of nutrients for lactation could affect fawn mortality rate, which may be significant (Knowlton et al. 1978). Welder Wildlife Refuge data (Unpublished data, Drawe) shows that fawn:doe ratios of 15 fawns: 100 does, 10 fawns: 100 does, 5 fawns: 100 does, and 15 fawns: 100 does during surveys made in 1987, 1988 , 1989 , and 1990 , respectively. The slight recovery of fawn:doe ratios in 1990 could be attributed to increased precipitation in the spring and summer that year, as well as the removal of all livestock from the refuge by winter of 1990 . Additionally, although CP content of deer diets was sufficient to satisfy the gestation requirements throughout the study, the low CP levels in summer and fall and the demands of lactation may prevent does from achicving estrous cycling, which in turn may result in low conception rates. Furthermore, malnutrition of does during the last stages of gestation will increase fawn mortality risks by affecting their immunological system (Sams et al. 1996). Teer et al. (1965) reported forage quality and availability as determinant factors influencing the reproductive performance of deer in the Llano Basin of Texas. Kie et al.(1980) pointed to low reproductive rates and ultimately a decline in deer populations, resulting from a low nutritional plane. Data from our study suggest that low nutrient values could have influenced declining fawn:doe ratios observed at the Welder Wildlife Refuge.

\section{Conclusions}

To improve deer habitat, a continuous yearlong grazing with moderate stocking rate is an important management option in the mesquite-mixedgrass. This management plan may provide whitetailed deer the opportunity for selecting diets containing more desirable forbs and greater nutrient concentration. Rotational grazing systems at moderate rates could also be used to maintain a relatively high seral stage. Several additional options (e.g., Merrill) could be implemented to balance the need for producing desirable deer forbs and at the same time, maintain rangeland in good condition. These options include intense livestock grazing at strategic times of the year coupled with adequate rest periods to restore plant vigor.

\section{Literature Cited}

AOAC. 1990. Official methods of analysis (15th ed.). Assoc. Off. Anal. Chem. Arlington, $\mathrm{Va}$

Arnold, L.A. and D.L. Drawe. 1979. Seasonal food habits of whitetailed deer in the south Texas plains. J. Range Manage. 32:175-178.
Bryant, F.C., M.M. Kothmann, and L.B. Merrill. 1979. Diets of sheep, Angora goats, Spanish goats and white-tailed deer under excellent range conditions. J. Range Manage. 32:412-417.

Bryant, F.C., C.A. Taylor, and L.B. Merrill. 1981. White-tailed deer diets from pastures in excellent and poor range condition. J. Range Manage. 34:193-200.

Chamrad, A.D., B.E. Dahl, J.G. Kie, and D.L. Drawe. 1978. Deer food habits in South Texas-status, needs and role in resource management pp. 133-142. In: D.L. Drawe (Ed.). Proc. First Welder Wildl. Found. Symp. Contribution B-7. Welder Wildl. Found. Sinton, Tex.

Drawe, D.L. 1967. Seasonal forage preferences of deer and cattle on Welder Wildlife Refuge. M.S. Thesis. Texas Tech Univ. Lubbock, Tex.

Drawe, D.L. 1968. Mid-summer diet of deer on the Welder Wildlife Refuge. J. Range Manage. 21:164-166.

Drawe, D.L. 1988. Effect of grazing management on cattle diets and nutrition in the coastal prairie. Tex. J. Agr. and Nat. Resources. 2:17-25.

Drawe, D.L. and J.E. Cox. 1978. A coordinated range research program for the Welder Wildlife Foundation Refuge. p. 34-43. In: D.L. Drawe (Ed.). Proc. First Welder Wildl. Found. Symp. Contribution B-7. Welder Wildl. Found. Sinton, Tex.

Durham, A.J., Jr. 1975. The botanical and nutritive composition of winter diets of cattle grazing prairie on the Texas Gulf Coast. M.S. Thesis. Texas A\&M Univ. College Station, Tex.

Everitt, J.H. and D.L. Drawe. 1974. Spring food habits of white-tailed deer in the south Texas plains. J. Range Manage. 27:15-20.

Everitt, J.H., C.L. Gonzalez, G.R. Scott, and B.E. Dahl. 1981. Seasonal food preferences of cattle on native range in the South Texas Plains. J. Range Manage. 34:384-388.

Frasure, J.R., B.E. Dahl, and G.R. Scott. 1978. Effect of range condition, range site, and grazing management on cattle diets in the Texas Coastal Bend. P. 44-52. In: D.L. Drawe (Ed.). Proc. of the First Welder Wildl. Found. Symp. Contribution B-7. Welder Wildlife Found. Sinton, Tex.

French, C.E., L.C. McEwen, N.D. Magruder, R.H. Ingram, and R.W. Swift. 1956. Nutrient requirements for growth and antler development in the white-tailed deer. J. Wildl. Manage. 3:221-232.

Galyean, M.L. 1984. Techniques and procedures in animal nutrition research. Dept. of Animal and Range Sci. New Mexico State Univ. Las Cruces, N.M.

Holechek, J.L., M. Vavra, and R.D. Pieper. 1982a. Botanical composition determination of range herbivore diets: a review. J. Range Manage. 35:309-315.

Holechek, J.L., M. Vavra, and R.D. Pieper. 1982b. Methods for determining the nutritive quality of range ruminants diets: a review. J. Anim. Sci. 54:363-378.

Jones, D.I.H. and A.D. Wilson. 1987. Nutritive quality of forage. pp. 64-89. In: J.B. Hacker and J.H. Ternouth (Eds.). The nutrition of herbivores. Academic Press, Inc. Orlando, Fla.

Kie, J.G., D.L. Drawe, and G. Scott. 1980. Changes in diet and nutrition with increased herd size in Texas white-tailed deer. J. Range Manage. 33:28-34.

Knowlton, F.F., M. White, and J.G. Kie. 1978. weight patterns of wild white-tailed deer in southern Texas. pp. 55-64. In: D.L. Drawe (Ed.) Proc. First Welder Wildl. Found. Symp. Contribution B-7, Welder Wildl. Found. Sinton, Tex.

McMahan, C.A. and C.W. Ramsey. 1965. Response of deer and livestock to controlled grazing in Central Texas. J. Range Manage. 18:1-7.

Meyer, M.W., R.D. Brown, and M.W. Graham. 1984. Protein and energy content of white-tailed deer diets in the Texas Coastal Bend. J. Wildl. Manage. 48:527-534.

Moen, A.N. 1973. Wildlife ecology. An analytical approach. W.H. Freeman and Company. San Francisco. pp. 333-356.

Murphy, D.A. and J.A. Coates. 1966. Effects of dietary protein on deer. Trans. N. Amer. Wildl. Conf. 31:129-138.

NRC. 1984. Nutrient requirements of beef cattle. Sixth Revised Edition, 1984. Nat.. Acad. of Sci.. Wash., D.C.

Ortega, I.M. 1991. Taming captive-born and wild-born white-tailed deer fawns. Tex J.Sci. 43:215-217. 
Ortega, I.M. 1991. Deer and cattle foraging strategies under different grazing systems and stocking rates. Ph.D. Diss., Texas Tech Univ., Lubbock, Tex.

Ortega, I.M., L.D. Perry, D.L. Drawe, F.C. Bryant. 1990. Observations on obtaining white-tailed deer fawns for experimental purposes. Tex. J. Sci. 42: 69-72.

Ortega, I.M., S. Soltero-Gardea, F.C. Bryant, and D.L. Drawe. 1997a. Evaluating grazing strategies for cattle: Deer forage dynamics. J. Range Manage. 50:615-621.

Ortega, I.M., S. Soltero-Gardea, F.C. Bryant, and D.L. Drawe. 1997b. Evaluating grazing strategies for cattle: Deer and cattle food partitioning. J. Range Manage. 50:622-630.

Ott, L. 1988. An introduction to statistical methods and data analysis. Third Edition. PWS-KENT Publishing Co. Boston, Mass.

Palmer, W.L., R.L. Cowan, and A.P. Ammann. 1976. Effect of inoculum source on in vitro digestion of deer foods. J. Wildl. Manage. 40:301-307.

Rittenhouse, R.L., C.L. Streeter, and D.C. Clanton. 1971. Estimating digestible energy from dry and organic matter in diets of grazing cattle. J. Range Manage. 24:73-75.

Rosiere, R.E., J.D. Wallace, and R.F. Beck. 1975. Cattle diets in semidesert grassland: nutritive content. J. Range Manage. 28:94-96.

Sams, M.G., R.L. Lochmiller, C.W. Qualls, Jr., D.M. Leslie, Jr., and M.E. Payton. 1996. Physiological correlates of neonatal mortality in an overpopulated herd of white-tailed deer. J. of Mamma. 77:179-190.

SAS. 1985. SAS User's Guide: Statistics, Version 5 Edition. SAS Institute Inc. Cary, N.C.
Short, H.L. 1971. Forage digestibility and diet of deer on southern upland range. J. Wildl. Manage. 35:698-706.

Short, H.L. 1975. Nutrition of southern deer in different seasons. J. Wildl. Manage. 39:321-329.

Soltero-Gardea, S., I.M. Ortega, and F.C. Bryant. 1994. Nutrient content of important deer forage plants in the Texas Coastal Bend. Texas J. Sci. 46:133-142.

Steel, R.G.D. and J.H. Torrie. 1980. Principles and procedures of statistics: A biometrical approach. 2nd. Ed. McGraw-Hill Book Co., N.Y.

Teer, J.G., J.W. Thomas, and E.A. Walker. 1965. Ecology and management of white-tailed deer in the Llano Basin of Texas. Wildl. Monogr. No. 15. Wildl. Soc.

Tilley, J.M.A. and R.A. Terry. 1963. A two stage technique for the in vitro digestion of forage crops. J. Brit. Grass. Soc. 18:104-111.

Ullrey, D.E., W.G. Youatt, H.E. Johnson, L.D. Fay, and B.L. Bradley. 1967. Protein requirements of white-tailed deer fawns. J. Wildl. Manage. 31:679-685.

Warren, RJ. and LJJ. Krysl. 1983. White-tailed deer food habits and nutritional status as affected by grazing and deer-harvest management. J. Range Manage. 36:104-109.

Vavra, M., R.W. Rice, and R.E. Bement. 1973. Chemical composition of the diet, intake, and gain of yearling cattle of different grazing intensities. J. Anim. Sci. 36:411-414.

Verme, L.J. and D.E. Ulirey. 1984. Whitetail biology and ecology physiology and nutrition. pp. 91-118. In: L.K. Halls (Ed.). Whitetailed Deer, Ecology and Management. Wildl. Manage. Inst. Wash., D.C.

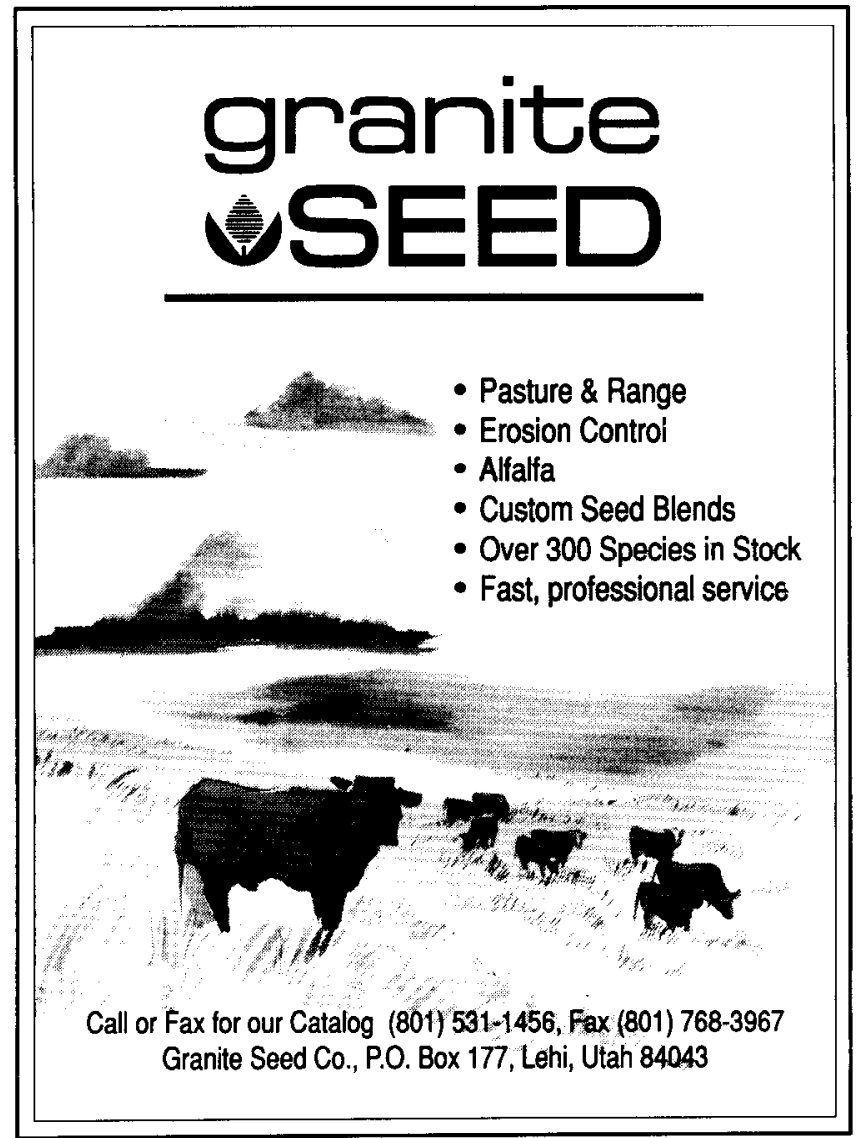

